University of Wollongong

Research Online

Faculty of Social Sciences - Papers (Archive) Faculty of Arts, Social Sciences \& Humanities

2014

Emerging geographies of conservation and Indigenous land in Australia

Heather Moorcroft

University of Wollongong, hm514@uowmail.edu.au

Michael Adams

University of Wollongong, madams@uow.edu.au

Follow this and additional works at: https://ro.uow.edu.au/sspapers

Part of the Education Commons, and the Social and Behavioral Sciences Commons

Research Online is the open access institutional repository for the University of Wollongong. For further information contact the UOW Library: research-pubs@uow.edu.au 


\title{
Emerging geographies of conservation and Indigenous land in Australia
}

\begin{abstract}
International examples of interactions between Indigenous peoples and the new conservation paradigm come mainly from developing countries and suggest divisions over priorities. As a Western settler society, Australia is at a critical time in conservation and Indigenous peoples' rights. Innovative approaches to conservation are promoted. The role and influence of non-governmental organisations is increasing. Indigenous peoples' rights to land are recognised and Indigenous involvement in conservation is growing. Yet, despite Australia being considered a leader in these arenas, particularly the latter, there has been little analysis of the relationship between innovative approaches to conservation and Indigenous Australians under the new paradigm. This paper describes how the spatial manifestations of approaches under the new conservation paradigm and Indigenous land in Australia are creating new geographies. We identify geographies of overlap, dichotomy and absence. The paper identifies research needs into these geographies, including: examining the influence of 'recognition' in engagements between conservation and Indigenous Australians; investigating the impacts of approaches under the new paradigm such as scaling-up, territorialism and differing governance structures on Indigenous Australians; and questioning the social responsibilities of the non-governmental organisations towards Indigenous Australians.
\end{abstract}

\section{Keywords}

indigenous, land, australia, emerging, geographies, conservation

Disciplines

Education | Social and Behavioral Sciences

Publication Details

Moorcroft, H. \& Adams, M. (2014). Emerging geographies of conservation and Indigenous land in Australia. Australian Geographer, 45 (4), 485-504. 
MANUSCRIPT TYPE: Article

TITLE: Emerging geographies of conservation and Indigenous land in Australia

AUTHORS: Heather Moorcroft and Michael Adams

AFFILIATION: Heather Moorcroft, Australian Centre for Cultural Environmental Research (AUSCCER), University of Wollongong, NSW, 2522, Australia, Email: hmoorcroft@bigpond.com; Michael Adams, Australian Centre for Cultural Environmental Research (AUSCCER), University of Wollongong, NSW, 2522, Australia, Email: madams@uow.edu.au.

ADDRESS FOR CORRESPONDENCE: Heather Moorcroft, Australian Centre for Cultural Environmental Research (AUSCCER), University of Wollongong, NSW, 2522, Australia, Email hmoorcroft@bigpond.com 


\section{Emerging geographies of conservation and Indigenous land in Australia}

ABSTRACT International examples of interactions between Indigenous peoples and the new conservation paradigm come mainly from developing countries and suggest divisions over priorities. As a Western settler society, Australia is at a critical time in conservation and Indigenous peoples' rights. Innovative approaches to conservation are promoted. The role and influence of nongovernment organisations is increasing. Indigenous peoples' rights to land are recognised and Indigenous involvement in conservation is growing. Yet, despite Australia being considered a leader in these arenas, particularly the latter, there has been little analysis of the relationship between innovative approaches to conservation and Indigenous Australians under the new paradigm. This paper describes how the spatial manifestations of approaches under the new conservation paradigm and Indigenous land in Australia are creating new geographies. We identify geographies of overlap, dichotomy and absence. The paper identifies research needs into these geographies, including: examining the influence of 'recognition' in engagements between conservation and Indigenous Australians; investigating the impacts of approaches under the new paradigm such as scaling-up, territorialism and differing governance structures on Indigenous Australians; and questioning the social responsibilities of the non-government organisations towards Indigenous Australians.

KEY WORDS Conservation; Indigenous people; NGOs; geographies; Australia; settler society; neocolonial; paradigm. 


\section{Introduction}

Recent analysis of conservation theory and practice has identified a rapidly evolving conceptual and management landscape. A new conservation paradigm, established in the late twentieth century on the premise that public efforts alone, centring on the declaration and management of state-owned national parks (the old paradigm), can not solve the biodiversity crisis facing the planet, is driving exploration of innovative approaches to biodiversity conservation. Approaches to conservation under the new paradigm have seen changes to the scale, territory and governance of conservation. Conservation is being carried out on a large scale, with landscape and continental-scale approaches gaining prominence (Worboys et al. 2010). Adoption of neoliberalist ideologies is resulting in a shifting of governance roles in conservation (Sundberg 2006), reflected in the growth of the involvement of nongovernmental organisations (NGOs), an increase in private protected areas (Pasquini et al. 2011) and the emergence of new and varied public-private partnerships and networks. Conservation territories have evolved to encompass not only national parks, but to also include working landscapes where biodiversity conservation is just one of potentially numerous land uses. With a growing awareness of Indigenous rights and an increase in Indigenous lands, the role of local and Indigenous communities in conservation is increasingly recognised (Kothari 2008). In addition, local-scale cultural approaches to conservation, including co-managed protected areas and Indigenous Peoples' and Community Conserved Territories and Areas (ICCAs) have expanded the conceptual basis for conservation internationally (Kothari 2008; Ross et al. 2011). At least some of these changes were initiated by the outcomes of the Fifth World Parks Congress in Durban 2003, which recognised that 'Indigenous and local communities bring special insight, diverse knowledge and active commitment' to conservation and environment issues (Vaz \& Agama 2013, p. 141).

Zimmerer (2006) describes how globalisation and the new approaches to conservation can create 'spaces of hope' with positive outcomes for both local and Indigenous people and for conservation. Complacency, lack of support, cost-shifting or inadequate resourcing for conservation and/or Indigenous rights by the state in some countries has led to NGOs assuming governance roles. Supporting this idea, descriptive publications, including those by stakeholders, relay stories of conservation NGOs empowering Indigenous people in decision-making and helping establish revenue streams (see Chicchón 2009), and opposing common threats to biodiversity such as urbanisation and agriculture, industrialisation and deforestation (see Alcorn et al. 2010). There are assertions that returning control of conservation lands to Indigenous peoples will achieve both environmental and social outcomes (e.g. Kothari 2008). Yet other literature explains that when the trajectories under the new paradigm intersect with Indigenous interests there are often divisions over priorities. Social outcomes may be pitched against conservation outcomes, and local agendas pitched against global agendas. Some contend that in areas of high conservation value social issues such as those relating to Indigenous people should not take precedence and conservation should be the focus (e.g. Terborgh 
1999; Oates 2006). A large literature critiques the engagements of conservation NGOs with Indigenous people (see Chapin 2004; Brockington \& Igoe 2006; Dowie 2009). Landscape and continental-scale approaches have also come under criticism, with reports that 'scaling-up' of conservation efforts has adverse consequences on Indigenous governance regimes and claims that international NGOs are linking community-designated conservation areas at scales that allow for global conservation agendas to dominate local aspirations (see Igoe \& Croucher 2007; Ramutsindela \& Noe 2012).

The majority of research on the intersection of Indigenous interests with the new conservation paradigm stems from case studies in the developing world. Research on these intersecting trajectories from the developed world is modest, particularly from the Western settler societies where the lives of Indigenous people are often represented as 'fourth world'.

The aims of this paper are: (1) to highlight the emerging geographies between approaches under the new conservation paradigm and Indigenous land in Australia; and (2) to redress the knowledge gap on these geographies to support a more inclusive and equitable path than that followed by earlier conservation efforts in relation to Indigenous Australians. We use the term 'emerging geographies' to identify new spatial and other patterns that reveal a changing landscape in Australia, where there are some new relationships between conservation and Indigenous interests, with potential for both positive and negative outcomes.

\section{Methods}

This paper is one outcome of a larger project that analyses relationships between the new conservation paradigm and Indigenous communities in Australia. The project uses interviews, participant observation and historical research. For this paper, after setting the Australian context, we examined the policy and spatial trajectories of the new conservation paradigm and Indigenous land. We analysed publicly available historical and contemporary documents of the state, particularly the Australian Government, and of seven conservation NGOs working at a national scale (the Australian Conservation Foundation; the Australian Wildlife Conservancy; Bush Heritage Australia; Greening Australia; The Wilderness Society; WWF-Australia; and The Nature Conservancy). The policy analysis identifies specific named objectives of the different organisations, and also reveals attitudes to Indigenous people and interests in Australia.

We used spatial analysis to identify national scale patterns. After adjusting for scale, we compared the contemporary spatial patterns of conservation and Indigenous lands to identify emerging geographic relationships. We are aware that conducting this analysis at a national scale masks complex smaller-scale geographic heterogeneity. The national scale, however, reveals the broad 
trajectories and relationships, and it is this scale that is chosen by both the conservation NGOs and the Australian Government in making statements about conservation objectives and achievements.

In our analysis of maps, we are aware that there are many challenging conceptual issues. Carolan (2009, p. 279) argues that maps have become 'an indispensable instrument in environmental science and policy due to their ability to depict aspects of reality that are otherwise difficult to see', but goes on to say that 'we must also not forget that these representations do more than depict reality; they also mask and distort it'. The maps we analyse here have the potential to reflect both these outcomes. Our analysis seeks to acknowledge issues around the 'neither neutral nor unproblematic' nature of maps (Carolan 2009, p. 279), but focus on the on-ground and policy relationships that these maps nevertheless begin to reveal. The maps we explore are not primarily the result of Indigenous 'countermapping' approaches, although they will sometimes include such mapping as outcomes of land claim and native title processes. Rather, they are maps that fit both conservation and Indigenous claims into established Western cartographic traditions. While we are aware of the need 'to problematize the spatial realities represented within the mapping process' (Johnson et al. 2006, p. 90), it is the influence of these apparently fixed maps we focus on here. A final point we acknowledge here is that the cadastral rendering of these territories ignores mobility. As Howitt et al. (2013, p. 132) argue, Indigenous Australian mobilities 'nurture their socio-cultural and spiritual identities, and economic livelihoods, and demonstrate their relationships to country', simultaneously disrupting dominant discourses of a stable cadastral grid.

\section{National context}

In Australia, early colonial processes of Indigenous dispossession have resulted in Indigenous people continuing to be socially disadvantaged. The colonial processes of appropriation and 'emptying the landscapes' to fill them with new things (Howitt 2001, p. 235) has resulted in considerable parts of the continent being held or owned under private or quasi-private tenure, such as leases on lands held by the Crown. Subsequent to the historic, often brutal, dispossession of Indigenous people from their homelands, social movements aimed at redressing Indigenous disadvantage led to legislative processes that have returned some lands to Indigenous Australians. By 2014, the outcomes of this are significant. Indigenous lands returned under Australian law, which Indigenous Australians own or control, mainly under various forms of community tenure, cover a significant portion of the continent, with 2012 estimates at approximately 23\% of the continent (Altman 2012). While there is much heterogeneity in tenure and governance on these lands, and much diversity of Indigenous culture and demography on them, they are distinctly different from other types of land ownership by nonIndigenous Australians.

Achieving this level of land ownership and control has come at a cost. Indigenous Australians have had to contest some of the public lands, the residual lands, with the state. During these historical 
contests Indigenous Australians have often been excluded and marginalised by state conservation efforts. Indigenous Australians have mostly not been physically displaced by the establishment of protected areas (Poirier \& Ostergren 2002; Goodall 2006), as in some other countries. However, they have had to compete for land with conservation (Adams 2004). For example, national parks have been declared without notification or consent from affected Indigenous people (Porter \& Meyers 2008), and jointly managed national parks have been established through coercion and/or compromise (Smyth 2001; Bauman \& Smyth 2007). Adams (2001) argued that Indigenous Australians were largely denied 'recognition space' by conservation organisations during these earlier engagements. Yet, despite the conflicts, contests and coercions, Australia is now seen as a leader in conservation on Indigenous-held lands (see Ross et al. 2011, p. 193). While in some respects this perception is legitimate, it is at least ironic that much of the progress in this area has been achieved by Indigenous protest and litigation, rather than progressive approaches by governments (see for example, Hibbard \& Lane 2004 on Mutawintji; and Farrier \& Adams 2011 on Booderee, both now Aboriginal-owned national parks).

Reflecting the global trend, Australia has embraced the new conservation paradigm, with various innovative approaches to conservation adopted (Figgis et al. 2012). Acknowledging that the government-managed national park system is inadequate to conserve the country's biodiversity, state initiated incentives and policies aim to increase the conservation estate not only with publicly owned lands, but also with private and Indigenous owned and controlled lands. Large-scale conservation efforts are promoted. The Australian conservation sector has evolved from dominance and control by the state to that of a multi-faceted sector that includes government, an increasing involvement of NGOs, such as not-for-profit organisations, philanthropists and corporations, as well as Indigenous communities.

Lane and Morrison (2006) highlighted risks associated with this increased role and influence of NGOs, and called for discussion on this issue to ensure public interests are not taken over by private agendas. With the geographical areas of new forms of conservation intersecting with the growing areas of Indigenous lands and increasing Indigenous involvement in conservation, the need for that discussion is pertinent. The emergent, yet still modest, literature on engagements between Indigenous interests and the new conservation paradigm in Australia supports this. As with the global research analysed above, there are mixed messages on the consequences, intended or otherwise, of these intersections.

Pickerill $(2008,2009)$ explored the use and power of language, and negotiating commonalities of difference, in engagements between Indigenous Australians and a number of not-for-profit conservation NGOs, concluding that although there are still 'problematic practices' (Pickerill 2009, p. 78), there is hope for improved engagements. Highlighting north-south disparities that are explored 
below, in Pickerill's research Indigenous engagements by the NGOs were based on the perception that there is 'no need to engage with Indigenous politics further south, perpetuating the myth that only those Indigenous people who have a more apparent and historic (according to non-Indigenous adjudicators) connection to their homeland need consultation' (Pickerill 2008, p. 102).

Reflecting the international literature, a number of descriptive publications by stakeholders indicate some positive engagements between Indigenous Australians and NGOs. Gunn et al. (2012) described collaborations between northern Australian Indigenous ranger groups and NGOs in addressing marine debris issues along the coastline. Moorcroft et al. (2012) explained how a collaboration between an Indigenous traditional owner group in the Kimberley region of Western Australia and external stakeholders, including the national not-for-profit conservation NGO Bush Heritage Australia, adapted an international conservation planning framework in a cross-cultural context to deliver both social and conservation outcomes.

A small number of research articles, as well as discussion in the media, centre on engagements of contest and conflict between NGOs and Indigenous Australians. Most of these relate to land tenure, planning and management of land and rights to land. John Holmes (2011, 2012) has highlighted the complexity of relationships between the conservation sector and Indigenous people in tenure reform processes of the contested landscapes of Queensland's Cape York Peninsula. In the media, the controversial Queensland Government's Wild Rivers legislation, supported by the national not-forprofit NGO, The Wilderness Society, drew vehement opinion pieces by prominent Aboriginal activist and lawyer Noel Pearson, claiming that the conservation sector and the legislation would restrict Indigenous people's ability to use and occupy their country (see Pearson 2010a, 2010b). Kerins (2009) accused another national conservation NGO, the Australian Wildlife Conservancy, of undermining Indigenous conservation initiatives and threatening Indigenous native title rights when it acquired a sub-lease from an Indigenous pastoral lease holder to operate a wildlife sanctuary.

Particularly relevant to this paper is a typology of case studies of environmental management collaborations with Indigenous organisations, including those involving not-for-profit organisations. The typology categorised collaborations into levels of Indigenous governance and showed that integration of Indigenous knowledge is strongest when the level of Indigenous governance is highest (Hill et al. 2012).

\section{Trajectories of change}

In Australia there is a particular set of conditions leading to the emerging geographies of conservation and Indigenous land. These include: neoliberalist governance approaches to conservation and changing Indigenous governance under the native title era; multiple use of space of both conservation and Indigenous land; large spatial scales of conservation and Indigenous land, particularly in some 
parts of the country; and a redefinition of conservation and Indigenous territories that reflects the interaction of complex spatial arrangements of ownership, management and institutional networks. In this section we set these changes in historic and spatial context.

Since the 1980s, the state has actively consulted with NGOs in development of environmental policy (Hutton \& Connors 1999). The conservation sector changed from a government arena, to one that included NGOs. With state support and financial assistance from the emerging philanthropic sector, some NGOs became active in on-ground conservation activities: planting trees; setting up covenanting systems for conservation on private lands; and acquiring and managing property (Figgis 2004; Cowell \& Williams 2006).

Consecutive governments at both provincial (state and territory) and national level in the 1990s provided further opportunities for NGOs to be involved in conservation. In the early 1990s the Australian Government created a framework for a National Reserve System (NRS) - a 'comprehensive, adequate, and representative' system of protected areas (ANZECC 1996). The aim of the NRS is to ensure that the continent's bioregions, under the planning framework of the Interim Biogeographic Regionalisation of Australia (IBRA), are adequately represented in protected areas (Thackway \& Creswell 1995). To help achieve the vision of a comprehensive, adequate and representative protected areas system, the NRS Program, up until 2013, provided funds to assist with the acquisition of land in the under-represented bioregions (Figure 1), for inclusion in the NRS. Tax incentives and concessions, and the funding arrangements under the NRS Program for acquisition of conservation lands, has led to a significant increase in the conservation estate.

FIGURE 1. Map showing the under-represented bioregions of the Interim Biogeographical Regionalisation of Australia (IBRA). Source: Australian Government (n.d.a).

One of the results of these government initiatives and incentives was that NGOs which were previously advocacy-focused increased their on-ground conservation effort on private lands. A suite of new not-for-profit conservation NGOs also emerged. These newer NGOs focus on acquisition and management of lands for conservation, as well as partnering with existing land owners, philanthropic organisations and governments. Recent NRS data shows that Indigenous-held or controlled lands and private protected areas have become significant contributors to the NRS (Figure 2) (Australian Government n.d.b).

FIGURE 2. Location and governance of protected areas in Australia's National Reserve System in 2012. Source: Australian Government (n.d.b). 
With the enactment of the first Indigenous land ownership legislation in 1966 in South Australia, the return of lands to Aboriginal people in Australia began. Other jurisdictions followed, as well as the Commonwealth in 1976, so that by the early- to mid-1990s all jurisdictions, with the exception of Western Australia and the Australian Capital Territory, had some form of Aboriginal land ownership legislation (Broome 2010). This legislation was largely framed as compensation for Indigenous disadvantage and dispossession. With land rights came formal governance structures for the management of Aboriginal land under Australian law.

In 1993 the Commonwealth Native Title Act recognised Indigenous peoples' traditional and customary rights and interests to land and sea under Australian common law where such title has not already been extinguished by the state. This provides Indigenous Australians with another avenue to gain title to land. In some cases, native title has provided clarity for the state and others wishing to consult or negotiate with Indigenous people on issues about land (Davies 2003). Native title, for some Indigenous communities, has provided 'recognition space' (Pearson 1997).

In the native title era, other forms of Indigenous governance structures developed. Recognising that native title of many parts of Australia had been extinguished, in 1995 the Australian Government established the Indigenous Land Corporation (ILC) to acquire, manage and hold land in trust for the benefit of Aboriginal people (Nettheim et al. 2002). Some lands acquired by the ILC have high biodiversity values and are being managed for conservation. In 1998, Indigenous Land Use Agreements (ILUAs) were introduced, providing a framework whereby some Indigenous Australians could negotiate the use and management of land and water, including conservation, whether there was native title determined or not (Davies 2003).

Support and recognition of conservation on private lands and an adoption of expanded protected area concepts have been critical changes to conservation, as has the use of Indigenous-held lands for contemporary economies and sustainable livelihoods. Recognising the expanded IUCN protected areas categories (IUCN 1994), the NRS allowed for several different types of protected areas including those on private lands and Indigenous lands. The climate change agenda, through the carbon market, is also driving an increase in multiple use approaches on conservation and Indigenous land. As one example, ConocoPhillips, the operator of the Darwin Liquefied Natural Gas plant, as part of both its corporate social responsibilities and to offset environmental impacts of its plant operations, agreed to support Aboriginal land owners and rangers with their work in reinstating fire management and protecting vegetation in western Arnhem Land. The success of the West Arnhem Land Fire Abatement (WALFA) Project has been widely acknowledged for a suite of environmental and social benefits (Whitehead et al. 2009).

With an increase in the Indigenous-held and controlled lands has come increased involvement of Aboriginal people in conservation. In recognition that much of the under-represented bioregions of 
the NRS were on Aboriginal titled land, the Australian Government developed the Indigenous Protected Area (IPA) concept in consultation with Indigenous Australians in the 1990s (Smyth \& Sutherland 1996), whereby Indigenous land holders can voluntarily agree to manage their land for conservation. Since dedication of the first IPA, Nantawarrina, in South Australia in 1998 (Smyth 2001; Muller 2003), IPAs are a major contributor to the NRS, and according to the latest public data there are 60 declared IPAs and 27 in the planning stage (Australian Government 2013a). The concept of protected areas has been further expanded with the utilisation of ILUAs. In 2011 Mandingalbay Yidinji became the first IPA to be declared over existing government protected areas as well as Indigenous land (Australian Government 2013b). In the Northern Territory, amendments to national park legislation in 2003 and 2005 have provided for the Aboriginal ownership and joint management of 27 national parks and reserves (Northern Territory Government 2014). Aboriginal involvement in conservation has also increased under the Australian Government's Working on Country Program, where since 2007 Indigenous rangers have been employed to deliver environmental conservation outcomes, often on their own IPAs. At the time of writing there are nearly 700 Working on Country rangers working across Australia (Australian Government 2014). These projects combine customary knowledge of elders with teams of young rangers. This also reflects international developments, with Vaz and Agama (2013, p. 154) identifying similar outcomes in Malaysia, where potential ICCAs are 'built upon a strong base of traditional knowledge from the older generation, and driven by the energy of young Indigenous people ... excited about advancing community governance in a modern context'.

Another change in the use of conservation and Indigenous spaces has been that large areas of Australia, particularly in the northern and western regions of the country, more remote from population centres, are subject to ongoing tenure reform processes. The Government of Western Australia is undertaking a rangelands reform process to develop new forms of land tenures, such as converting pastoral leases to longer term perpetual leases, redefining leases to allow for conservation purposes and take account of native title (Government of Western Australia 2014). These processes can change agricultural spaces into multi-functional and multi-tenure landscapes with a mix of conservation, agriculture and Indigenous spaces. Work on Queensland's Cape York Peninsula (Holmes 2011, 2012), describes the spaces undergoing such reform processes as contested landscapes, where there is often conflict between Indigenous aspirations and conservation goals.

The large spatial scale of conservation and Indigenous-held land is another feature of the emerging geographies of conservation and Indigenous land. As is the case globally in biodiversity conservation, in Australia there has been a shift from a species-specific approach to a landscape or continental-scale approach. This large-scale approach means that such landscapes invariably contain multiple land uses. Working landscapes, such as rural and agricultural lands, industrial areas, urban and peri-urban blocks, are all encompassed within the larger scale. Many not-for-profit NGOs have adopted this 
larger scale approach to their on-ground conservation efforts through acquisition and management of properties for conservation within these landscapes, or through working with existing land holders.

Linked to the large-scale conservation approach is the concept of connectivity corridors: developing and maintaining viable ecosystems on private land to link and buffer protected areas, and to build resilience to the impacts of climate change. The corridors are intended to deliver social and economic benefits as well as conservation outcomes (Mackey et al. 2010). The approach has gained recognition with both government and NGOs in Australia, and a proposed national network of landscape and transcontinental-scale corridors has been identified in the National Wildlife Corridor Plan (Australian Government n.d.c). Within each of the corridors there are collaborations with NGOs active in on-ground conservation on private lands. Indigenous-held or controlled lands also feature in the corridors, particularly in northern and central Australia.

Parallel to these changing scales of conservation efforts has been a change of scale of Indigenous land recognised under Australian law. Native title determinations have returned considerable areas of land to Indigenous people in the north and especially in Western Australia. However, rapid and intensive colonisation of south-eastern Australia, and subsequently south-western Australia, resulted in massive forced displacement of Aboriginal people, with loss of their lands and extinguishment of native title in many instances. In these areas while many small parcels of land have been regained, it is at a much smaller scale.

Reflecting the interaction of complex spatial arrangements of management and institutional networks, there has been a redefinition of conservation and Indigenous territories in Australia. Under the new conservation paradigm, the discrete spaces of national parks have been expanded with the adoption of larger-scale and different types of conservation efforts. The specific spatial interests or conservation territories of the NGOs reflect priorities of the NRS, international conservation priorities, and/or specific charters of the organisations. The Australian Conservation Foundation has 'a sustainable future for northern Australia based on the rights and interests of Indigenous peoples' as a national agenda item (http://tinyurl.com/acf-agenda). The Australian Wildlife Conservancy (AWC) has a concentration of sanctuaries in northern Australia and the south-west (http://tinyurl.com/awcmap1). Bush Heritage Australia (BHA) has its 'anchor regions' including the Gulf of Carpentaria to Lake Eyre in northern Australia, the Tasmanian Midlands and the south-west (http://tinyurl.com/bhamap1). Greening Australia has many projects around Australia but its 'visionary projects' are focused in the south-west, the east coast and south-east with growing initiatives in northern Australia (http://tinyurl.com/ga-map1). The Wilderness Society has several geographical areas of interest with a focus on Cape York Peninsula, the Kimberley and the south-east (http://tinyurl.com/tws-12-13). WWF-Australia, under its current strategic plan, has the Kimberley and the south-west eco-region as a focus of its conservation framework (http://tinyurl.com/wwf-australia-strategic-plan). The Nature 
Conservancy, who as well as partnering with government, Indigenous groups and funding the efforts of national conservation NGOs such as BHA and AWC, has a focus on regions of international biological significance of northern Australia and the south-west (http://tinyurl.com/tnc-australia-map). A number of the NGOs also have Indigenous partnerships programs.

This concept of national-scale conservation territories is explicit in two of the NGOs that specifically assert the significance of the scale of their operations. The Australian Wildlife Conservancy, at early 2014, has 23 sanctuaries covering over 3 million hectares and 'owns and manages for conservation more land than any other non-government environment organisation in Australia’ (AWC n.d.). Bush Heritage Australia manages 35 reserves covering just less than one million hectares with conservation covenants, and aims to protect 1 per cent of Australia 'by acquiring and managing land of outstanding conservation value, or by working in partnership with other landowners’ (BHA 2014).

To show the areas of interest, and the level of interest, of conservation under the new paradigm at a national scale in Australia, we have overlaid maps of the terrestrial geographical interests of the NGOs mentioned above and the connectivity corridors of the National Wildlife Corridor Plan (Figure 3).

FIGURE 3. Terrestrial geographical areas of interest, and level of interest, of conservation under the new paradigm in Australia.

As well as the individual conservation territories of the different organisations, at a large scale another outcome is illustrated in Figure 3. The level of interest of the conservation NGOs operating in Australia corresponds with the global phenomena of large conservation NGOs from the 'north' or developed countries, operating in the countries of the 'south'. From the intensity of shading on the map it is evident that there is a geographical divide also occurring in Australia. Although the south is not ignored, the map in Figure 3 shows a much lower level of interest in the central and western desert regions of the country, and an intense focus on northern Australia.

In 2012 Indigenous-titled land, shown at a national scale in Figure 4, equated to approximately 1.7 million square kilometres (23 per cent) of the continent's land area (Altman 2012). This includes lands held as 'exclusive possession' under native title, as well as lands scheduled or claimed under Aboriginal land rights legislation. If non-exclusive possession under native title is included, 33 per cent of the continent is held under some form of Indigenous titled land (Altman 2014). Although maps at this national scale have limitations (smaller areas of Aboriginal land are not spatially represented and the constant changes to land tenure and title make it difficult to maintain accuracy), the map indicates that most areas of Indigenous-held or controlled lands are in the north, north-west and 
central regions, with very little in the south-east and south-west. Large numbers of Aboriginal people live in the south-east and south-western areas, with an increasing concentration of Indigenous people in both major cities and regional centres, and nearly one-third of the Indigenous population living in densely settled areas of the east coast (Australian Bureau of Statistics 2012). With the spatial extent of registered native title claims expanding into some of these more settled regions, particularly the southwest, up to an additional 40 per cent of lands could be held under some form of Indigenous title, resulting in approximately 70 per cent of the continent held under some form of Indigenous titled land (Altman 2014).

FIGURE 4. Map of the Indigenous titled lands in Australia, also showing discrete Indigenous communities. Source: Altman 2012 @ Federation Press, Sydney.

In response to these changes in demography and tenure, non-spatial forms of Indigenous relationships are also developing, linking the trajectories of the new conservation paradigm and Indigenous land. Indigenous conservation networks and associations are emerging, such as the North Australian Indigenous Land and Sea Management Alliance (NAILSMA), a not-for-profit organisation that assists Indigenous people across northern Australia in land and sea management (NAILSMA 2013). These represent another form of governance structure for negotiation and consultation.

\section{Emerging geographies of conservation and Indigenous land}

By overlaying a single shading of the combined interests of the new conservation paradigm map (Figure 3) with the Indigenous titled lands map (Figure 4), a number of spatial patterns are evident (Figure 5). We classify these into three categories, discussed below. There are a number of challenges both revealed by and inherent in this process. As they are at the national scale, they obscure finegrained heterogeneity. They suggest equivalent management capacity and resources, where there are in fact significant differences within and between Indigenous organisations and NGOs that our interviews revealed. They also compare a static spatial depiction of current Indigenous landholdings with a prospective area of engagement of the NGOs, when both of these are dynamic and contested.

FIGURE 5. Map showing emerging geographies of conservation and Indigenous lands in Australia. (Indigenous lands adapted from Altman (2012)).

\section{Geography of overlap}

There is considerable overlap between the geographical interests under the new conservation paradigm and Indigenous land in the tropical savannas of northern Australia and in the deserts of central Australia. These regions are in the most part remote, with isolated Indigenous communities, 
large cattle stations, mining towns and conservation estate. Many different tenures are represented, including pastoral leases, national parks, Aboriginal reserve lands in Northern Territory and Queensland and large areas of what was unallocated Crown lands, much of which has been or is being claimed under native title. And as discussed above, much of these regions of overlap are also undergoing tenure reform processes, often resulting in conflict and contested landscapes.

\section{Geography of absence}

There are regions of Australia where there is neither much Indigenous land nor geographical interest under the new conservation paradigm. Similar to the geography of overlap above, these regions are remote and are made up of mixed tenures. The arid mid-western region of Western Australia is one such area. Mining in this region is of particular importance (Government of Western Australia 2013), and much of the region is also currently subject to registered native title claims (Native Title Tribunal 2013). Although this region and others under the geography of absence cover bioregions that are under-represented by the Australian Government's IBRA, they do not appear as areas of interest under the new conservation paradigm.

\section{Geography of dichotomy}

There are considerable regions of little or no overlap between the geographical interests of the new conservation paradigm and Indigenous-held land. Such regions include areas where there is either no or little Aboriginal-held land, such as in the east and south-western parts of the country, or where there is no geographical interest under the new conservation paradigm, such as in the central and western deserts. Sizable regions of interest of the NGOs are in areas with little Indigenous-held land, but include areas where many Indigenous people live, for instance in the south-east and south-west of the continent. In some of these regions, there have been conflicts between Aboriginal people and the conservation sector in the past. And although not evident in the maps, in densely settled parts of Australia, competition between Aboriginal organisations and conservation agencies for access to remaining Crown land has resulted in court decisions that have delivered some lands of 'high conservation value' to Aboriginal land councils (Adams 2004, p. 8). Most of the land in these regions is private land. In a number of the regions of conservation interest there are ILUAs, which does mean that negotiation and consultation between land owners and Indigenous Australians on some land issues is required.

\section{Conclusion}

Australia is at a critical point in conservation and Indigenous rights. We consider that the role and influence of NGOs in conservation in Australia is likely to increase, as evident from the policies and trajectories of the NGOs and government initiatives and policies. Coupled with this increase in private conservation will be an increase in Indigenous-held lands. The amount of land secured by Indigenous 
Australians through land rights is likely to slow. However, many native title claims are yet to be determined; the ILC is still purchasing properties with the aim of handing them back to traditional Indigenous owners; and hundreds of ILUAs are being negotiated. Indigenous involvement in conservation will increase with the expected declaration of IPAs that are currently in the planning stages, the implementation of ILUAs and the management of some ILC purchased lands for conservation. The need for financial support for the ongoing management of IPAs is bringing about partnership engagements between NGOs and Indigenous Australians. Landscape and continentalscale conservation, tenure reform processes and the increasingly influential climate change agenda will be catalysts for further engagements. The trajectories of the new conservation paradigm and Indigenous-held lands (and lands managed with involvement of Indigenous people) will become even more interwoven. Biodiversity conservation is consequently linked to the challenge of responding to social justice issues for Indigenous Australians.

International literature on the intersection of the new conservation paradigm and Indigenous interests suggests mixed outcomes for Indigenous people, with recognition in some circumstances, and denial in others. Analysis of these emerging geographies of conservation and Indigenous land is so far limited in the Western settled society of Australia. Yet historically, Indigenous Australians have suffered very significant dispossession and marginalisation, and efforts under the old conservation paradigm have contributed to this. While some elements of these impacts have been addressed for some people, there is a risk that colonial processes and outcomes could be replayed in contemporary scenarios. Indigenous Australians contribute very significantly to Australia's conservation efforts, through land management of over 23 per cent of the country, through management of a significant proportion of the nation's conservation estate and through their unique knowledge and customary practices. While Australia has been lauded as a global leader in Indigenous shared governance of protected areas, there are new questions about how approaches under the new conservation paradigm might evolve and their relationship with Indigenous Australians.

To what extent is recognition of Indigenous interests acknowledged in these emerging geographies? Are the historical colonial processes of public conservation efforts manifesting themselves in new kinds of neo-colonial consequences? What is the nature of the engagements between the conservation sector and Indigenous Australians in these emerging geographies? Do the geographies of overlap represent 'spaces of hope' (see Zimmerer 2006, p. 71) as well as spaces of contest and conflict? Are there engagements between conservation and Indigenous Australians in the geographies of dichotomy, or does this pattern deny recognition? Are there engagements in the geographies of absence, or do such absences ignore other conservation and Indigenous issues and opportunities. What are the consequences of these engagements? Through all of these, what is the role of maps: how are particular depictions of reality recruited, and who are they meant to influence? 
As noted by Lane and Morrison (2006), increased roles of the NGOs come with issues of representation, accountability and transparency. With significant public funds being used to help NGOs acquire and/or manage conservation lands in aid of developing the nation's protected area system and conserving the nation's biodiversity, it is appropriate to question the social responsibilities of these organisations towards some of the most disadvantaged members of the community Indigenous Australians. Similarly, it seems appropriate to consider whether such public funds could alternatively secure such properties and support the capacity development of the local Indigenous communities to deliver conservation objectives. Howitt et al. (2013, p. 128) also identify the challenge of persistent 'intercultural capacity deficits of dominant institutions, processes and knowledge systems' and the need for 'intercultural competence and the development of new capacities and competencies in those institutions'.

As has happened elsewhere, it appears that the geographical interests of conservation under the new paradigm in Australia may reflect some complacency, inadequacy or cost-shifting by the state in conservation and/or Indigenous rights. If so, it is important to ask how NGOs assume or are given governance roles in such regions, and what the impacts on Indigenous governance structures and aspirations are. The conclusion of Hill et al. (2012), that integration of Indigenous knowledge is strongest when the level of Indigenous governance is highest, suggests that Indigenous knowledge is only considered legitimate when power is held by the Indigenous party. Such interpretations further question the roles of power and legitimacy in engagements between the conservation sector and Indigenous Australians in the emerging geographies. It is important to find out the bases of power in engagements and how they impact on the legitimacy of Indigenous peoples' views, knowledge and aspirations. Related to this is the impact that the proprietary non-Indigenous relationship to land and the desire of some NGOs to own land to achieve conservation outcomes has on engagements with Indigenous Australians.

From the reports and strategies of the conservation NGOs examined there is not only a geographical divide between north and south in their interests. There is also some form of geographical sharing of the country by the organisations, with some active in some regions and not in other regions. It is important to investigate the driving forces behind these processes of territorialism, and the roles that Indigenous lands and people play, and to encourage a more co-ordinated national strategic approach by the NGOs.

Landscape and continental-scale approaches to conservation being promoted and adopted in Australia have had negative consequences for Indigenous people in other countries. Large international organisations have been accused of linking, or 'scaling-up', conservation efforts across a larger geographical area to meet national or international biodiversity goals and by doing so have undermined and threatened local peoples' aspirations. And although the Australian situation may be 
different to those of developing countries, with the increase in national and international conservation NGOs operating in Australia, the consequences on Indigenous Australians of 'scaling-up' of conservation efforts to meet national or international agendas needs to be understood.

While both conservation and broader Indigenous social justice questions need input from multiple disciplines, we highlight these social perspectives to balance what is often an ecological emphasis in conservation discussions.

\section{Acknowledgements}

We would like to acknowledge and thank Lesley Head, Jack Baker, Richie Howitt and Jon Altman for their thoughtful insights and suggestions on this paper. We also thank Lois Haywood and David Clifton for help in preparation of some of the maps.

\section{REFERENCES}

ADAMS, M. (2001) Redefining relationships: Aboriginal interests and biodiversity conservation in Australia, Doctor of Philosophy Thesis, School of Geosciences, University of Wollongong, available from: http://ro.uow.edu.au/theses/1979 (accessed 4 February 2014).

ADAMS, M. (2004) 'Negotiating nature: collaboration and conflict between Aboriginal and conservation interests in New South Wales, Australia', Australian Journal of Environmental Education 20(1), pp. 3-11.

ALCORN, J.B., ZARZYCKI, A. \& DE LA CRUZ, L.M. (2010) 'Poverty, governance and conservation in the Gran Chaco of South America', Biodiversity 11(1 \& 2), pp. 39-44.

ALTMAN, J.C. (2012) 'People on country as alternate development', in Altman, J. \& Kerins, S. (eds) People on country. Vital landscapes Indigenous futures, pp. 1-36, The Federation Press, Sydney.

ALTMAN, J.C. (2014) The political ecology and political economy of the Indigenous land titling 'revolution’ in Australia. Mãori Law Review - Indigenous Law Speaker Series 2014.

ANZECC (AUSTRALIAN AND NEW ZEALAND ENVIRONMENT CONSERVATION COUNCIL) (1996) National strategy for the conservation of Australia's biological diversity, Department of the Environment, Sport and Territories, Canberra, ACT, available from: http://nrmonline.nrm.gov.au/catalog/mql:2330 (accessed 14 October 2014).

AUSTRALIAN BUREAU OF STATISTICS (2012) 2075.0 - Census of population and housing counts of Aboriginal and Torres Strait Islander Australians, 2011, available from: http://www.abs.gov.au/ausstats/abs@.nsf/Lookup/2075.0main+features42011～(accessed 4 February 2014). 
AUSTRALIAN GOVERNMENT (n.d.a) Australia's bioregions (IBRA), available from: http://www.environment.gov.au/parks/nrs/science/bioregion-framework/ibra/index.html (accessed 4 February 2014).

AUSTRALIAN GOVERNMENT (n.d.b) Ownership of protected areas, available from: http://www.environment.gov.au/parks/nrs/about/ownership.html (accessed 4 February 2014).

AUSTRALIAN GOVERNMENT (n.d.c) National Wildlife Corridor Plan, available from: http://www.environment.gov.au/biodiversity/wildlife-corridors/index.html (accessed4 February 2014).

AUSTRALIAN GOVERNMENT (2013a) Locations of Indigenous Protected Areas in Australia August 2013, available from: http://www.environment.gov.au/indigenous/images/ipa-map.jpg (accessed 12 May 2014).

AUSTRALIAN GOVERNMENT (2013b) Mandingalbay Yidinji Indigenous Protected Area, available from: http://www.environment.gov.au/indigenous/ipa/declared/mandingalbay.html (accessed 4 February 2014).

AUSTRALIAN GOVERNMENT (2014) About Working on Country, available from: http://www.environment.gov.au/indigenous/workingoncountry/index.html (accessed 4 February 2014).

AUSTRALIAN WILDLIFE CONSERVANCY (n.d.) About Australian Wildlife Conservancy. AWC facts, available from: http://www.australianwildlife.org/About-AWC.aspx (accessed 4 February 2014).

BAUMAN, T. \& SMYTH, D. (2007) Indigenous partnerships in protected area management in Australia: three case studies, Aboriginal Studies Press, Australian Institute of Aboriginal and Torres Strait Islander Studies and The Australian Collaboration, Canberra.

BROCKINGTON, D. \& IGOE, J. (2006) 'Eviction for conservation: A global overview', Conservation and Society 4(3), pp. 242-470.

BROCKINGTON, D. \& SCHOLFIELD. K. (2010) 'The conservationist mode of production and conservation NGOs in sub-Saharan Africa', Antipode 42(3), pp. 551-575.

BROOME, R. (2010) Aboriginal Australians: a history since 1788, Allen and Unwin, Crows Nest, Australia.

BUSH HERITAGE AUSTRALIA (2014) Bush Heritage Australia, available from: http://www.bushheritage.org.au/ (accessed 14 February 2014).

CAROLAN, M.S. (2009) "This is not a biodiversity hotspot”: the power of maps and other images in the environmental sciences, Society and Natural Resources 22, pp. 278-286.

CHAPIN, M. (2004) ‘A challenge to conservationists’, World Watch 17(6), pp. 17-31.

CHICCHÓN, A. (2009) 'Working with Indigenous peoples to conserve nature: examples from Latin America', Conservation and Society 7(1), pp. 15-20. 
COWELL, S. \& WILLIAMS, C. (2006) 'Conservation through buyer-diversity: a key role for not-forprofit land-holding organizations in Australia’, Ecological Management \& Restoration 7(1), pp. 520.

DAVIES, J. (2003) 'Contemporary geographies of Indigenous rights and interests in rural Australia’, Australian Geographer 34(1), pp. 19-45.

DOWIE, M. (2009) Conservation refugees: the hundred-year conflict between global conservation and native peoples, Massachusetts Institute of Technology, Massachusetts.

FARRIER, D. \& ADAMS, M. (2011) 'Indigenous - government co-management of protected areas: Booderee National Park and the national framework in Australia', B. Lausche, Guidelines for Protected Area Legislation, pp. 1-40 ‘Special Protected Area Types’ IUCN, Gland, Switzerland.

FIGGIS, P. (2004) Conservation on private lands: the Australian experience, IUCN, Gland, Switzerland and Cambridge, UK.

FIGGIS, P., FITZSIMONS, J.A. \& IRVING, J. (eds) (2012) Innovation for 21st Century Conservation, Australian Committee for IUCN, Sydney.

GOODALL, H. (2006) 'Exclusion and re-emplacement. Tensions around protected areas in Australia and southeast Asia', Conservation and Society 4(3), pp. 383-395.

GOVERNMENT OF WESTERN AUSTRALIA (2014) Rangelands Reform, available from: http://www.rdl.wa.gov.au/programsandprojects/pastoral/rangelandreform/Pages/Default.aspx (accessed 27 February 2013).

GOVERNMENT OF WESTERN AUSTRALIA (2013) Mid West Development Commission. Economy, available from: http://www.mwdc.wa.gov.au/Economy.aspx (accessed 4 February 2014).

GUNN, R., HARDESTY, B.D. \& BUTLER, J. (2010) 'Tackling 'ghost nets': local solutions to a global issue in northern Australia’, Ecological Management \& Restoration 11(2), pp. 88-98.

HIBBARD, M. \& LANE, M. (2004) 'By the seat of your pants: indigenous action and state response', Planning Theory \& Practice 5(1), pp. 97-104,

HILL, R., GRANT, C., GEORGE, M., ROBINSON, C.J., JACKSON, S. \& ABEL, N. (2012) 'A typology of indigenous engagement in Australian environmental management: implications for knowledge integration and social-ecological system sustainability', Ecology and Society 17(1), pp. 23.

HOLMES, J. (2011). 'Contesting the future of Cape York Peninsula', Australian Geographer 42(1), pp. 53-68.

HOLMES, J. (2012) 'Cape York Peninsula, Australia: A frontier region undergoing a multifunctional transition with indigenous engagement', Journal of Rural Studies 28, pp. 252-265.

HOWITT, R. (2001) 'Frontiers, borders, edges: liminal challenges to hegemony of exclusion', Australian Geographical Studies 39(2), pp. 233-245. 
HOWITT, R., DOOHAN, K., SUCHET-PEARSON, S., CROSS, S., LAWRENCE, R., LUNKAPIS, G., MULLER, S., PROUT, S. \& VELAND, S. (2013) 'Intercultural capacity deficits: contested geographies of coexistence in natural resource management', Asia Pacific Viewpoint 54 (2), pp. 126-140.

HUTTON, D. \& CONNORS, L. (1999) A history of the Australian environment movement, Cambridge University Press, Cambridge.

IGOE, J. \& CROUCHER, B. (2007) 'Conservation, commerce and communities: The story of community-based Wildlife Management Areas in Tanzania's northern tourist circuit', Conservation and Society 5(4), pp. 534-561.

JOHNSON, J., LOUIS, R.P. \& PRAMANO, A.H. (2006) 'Facing the future: encouraging cartographic literacies in Indigenous communities', ACME 4 (1), pp. 80-98.

KERINS, S. (2009) 'Black lands should be in black hands', National Indigenous Times - The Big Read, 22 January.

KOTHARI, A. (2008) 'Protected areas and people: The future of the past', Parks 17(2), pp. 23-34.

LANE M.B. \& MORRISON, T.H. (2006) 'Public interest or private agenda? A meditation on the role of NGOs in environmental policy and management in Australia', Journal of Rural Studies. 22, pp. 232-242.

MACKEY, B., WATSON, J. \& WORBOYS, G.L. (2010) Connectivity conservation and the Great Eastern Ranges corridor. An independent report to the Interstate Agency Working Group (Alps to Atherton Connectivity Conservation Working Group) convened under the Environment Heritage and Protection Council/Natural Resource Management Ministerial Council, Canberra.

MOORCROFT, H., IGNJIC, E., COWELL, S., GOONACK, J., MANGLOMARA, S. OOBAGOOMA, J., KARADADA, R., WILLIAMS, D. \& WAINA, N. (2012) 'Conservation planning in a cross-cultural context: the Wunambal Gaambera Healthy Country Project in the Kimberley, Western Australia’, Ecological Management \& Restoration 13(1), pp. 16-25.

MULLER, S. (2003) Towards decolonisation of Australia's protected area management: the Nantawarrina Indigenous Protected Area experience. Australian Geographical Studies 41(1), pp. $29-43$.

NATIVE TITLE TRIBUNAL (2013) Claimant applications as per the Register of Native Title Claims, available from: $\quad$ http://www.nntt.gov.au/Mediation-and-agreement-makingservices/Documents/Quarterly\%20Maps/RNTC_map.pdf (accessed 4 February 2014).

NETTHEIM, G., MEYERS, G.D. \& CRAIG, D. (2002) Indigenous people and governance structures. A comparative analysis of land and resource management rights, Aboriginal Studies Press, Australian Institute of Aboriginal and Torres Strait Island Studies, Canberra.

NORTH AUSTRALIA INDIGENOUS LAND AND SEA MANAGEMENT ALLIANCE (2013) Looking after country our way, available from: http://www.nailsma.org.au/about (accessed 4 February 2014). 
NORTHERN TERRITORY GOVERNMENT (2014) Joint management, available from: http://parksandwildlife.nt.gov.au/manage/joint\#.U3AYorGKC70 (accessed 12 May 2014).

OATES, J.F. (2006) 'Conservation, development and poverty alleviation: time for a change in attitudes', in Lavigne, D. (ed) Gaining ground in pursuit of ecological sustainability, pp. 277-284, International Fund for Animal Welfare, Guelph, Canada and the University of Limerick, Limerick, Ireland.

PASQUINI, L., FITZSIMONS, J.A., COWELL, S., BRANDON, K. \& WESCOTT, G. (2011) 'The establishment of large private nature reserves by conservation NGOs: key factors for successful implementation', Oryx - The International Journal of Conservation 45(3), pp. 373-380.

PEARSON, N. (1997a) 'The concept of native title at common law', In Yunupingu, G. (ed) Our Land is Our Life, pp. 150-162, University of Queensland Press. Brisbane.

PEARSON, N. (2010a) 'Labor connives with green alliance to control indigenous growth', The Australian, 16 January.

PEARSON, N. (2010b) 'Decision is in: Wild Rivers laws stink', The Australian, 2 October.

PICKERILL, J. (2008) 'From wilderness to WildCountry: the power of language in environmental campaigns in Australia’, Environmental Politics 17(1), pp. 95-104.

PICKERILL, J. (2009) 'Finding common ground? Spaces of dialogue and the negotiation of Indigenous interests in environmental campaigns in Australia', Geoforum 40, pp. 66-79.

POIRIER, R. \& OSTERGREN, D. (2002) 'Evicting people from nature: Indigenous land rights and national parks in Australia, Russia, and the United States', Natural Resources Journal 42, pp. 331351.

PORTER, M. \& MEYERS, G.D. (2008) 'Indigenous joint management of national parks in Western Australian', eLaw Journal: Murdoch University Electronic Journal of Law 15, pp. 262-274.

RAMUTSINDELA, M. \& NOE, C. (2012) 'Scalar thickening: wildlife management areas and conservation scales in southeast Tanzania’, Singapore Journal of Tropical Geography 33, pp. 137151.

ROSS, A., PICKERING SHERMAN, K., SNODGRASS, J.G., DELCORE, H.D. \& SHERMAN, R. (2011) Indigenous peoples and the collaborative stewardship of nature. Knowledge binds and institutional conflicts, Left Coast Press, Walnut Creek, CA.

SMYTH, D. (2001) 'Joint management of national parks', in Baker, B., Davies, J. \& Young, E. (eds) Working on country: contemporary Indigenous management of Australia's lands and coastal regions, pp. 75-91, Oxford University Press, South Melbourne.

SMYTH, D. \& SUTHERLAND, J. (1996) Indigenous Protected Areas. Conservation partnerships with Indigenous landholders. Report for Environment Australian, Commonwealth of Australia. Canberra. 
SUNDBERG, J. (2006) 'Conservation, globalization, and democratization: exploring the contradictions in the Maya Biosphere Reserve, Guatemala', in Zimmerer, K.S. (ed) Globalization and new geographies of conservation, pp. 259-276, University of Chicago Press, Chicago.

TERBORGH, J. (1999) Requiem for nature, Island Press, Washington.

THACKWAY, R. \& CRESSWELL, I.D. (1995) An interim biogeographic regionalisation for Australia: a framework for setting priorities in the National Reserves System Cooperative Program, Version 4.0, Australian Nature Conservation Agency, Canberra.

VAZ, J. \& AGAMA, A.L. (2013) 'Seeking synergy between community and state-based governance for biodiversity conservation: the role of Indigenous and Community-Conserved Areas in Sabah, Malaysian Borneo’ Asia Pacific Viewpoint 54 (2), pp. 141-157.

WHITEHEAD, P., PURDON, P., COOKE, P., RUSSELL-SMITH, J. \& SUTTON, S. (2009) 'The Western Arnhem Land Fire Abatement (WALFA) Project', in Russell-Smith, J., Whitehead, P. \& Cooke, P. Culture, ecology and economy of fire management in north Australian savannas: rekindling the wurrk tradition, pp. 287-312, CSIRO Publishing, Canberra.

WORBOYS, G., FRANCIS, W.L. \& LOCKWOOD, M. (2010) Connectivity conservation management: a global guide, Earthscan, London.

WORLD CONSERVATION UNION (IUCN) (1994) Guidelines for protected area management categories, IUCN, Gland and Cambridge.

ZIMMERER, K.S. (2006) 'Cultural ecology: at the interface with political ecology - the new geographies of environmental conservation and globalization', Progress in Human Geography 30(1), pp. 63-78.

\section{LIST OF FIGURES}




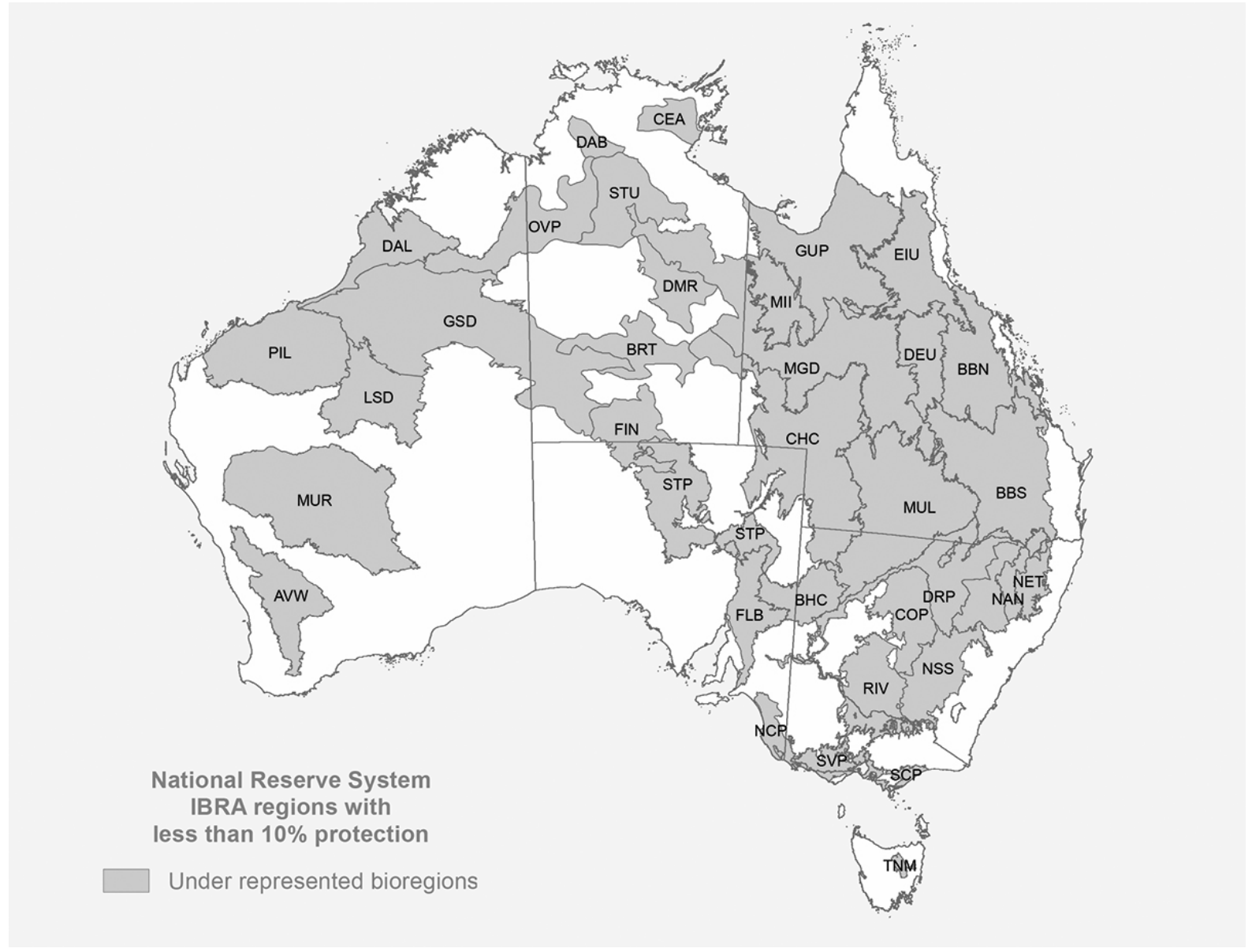

Figure 1: Map showing the under-represented bioregions of the Interim Biogeographical Regionalisation of Australia (IBRA). Source: Australian Government (n.d.a). 


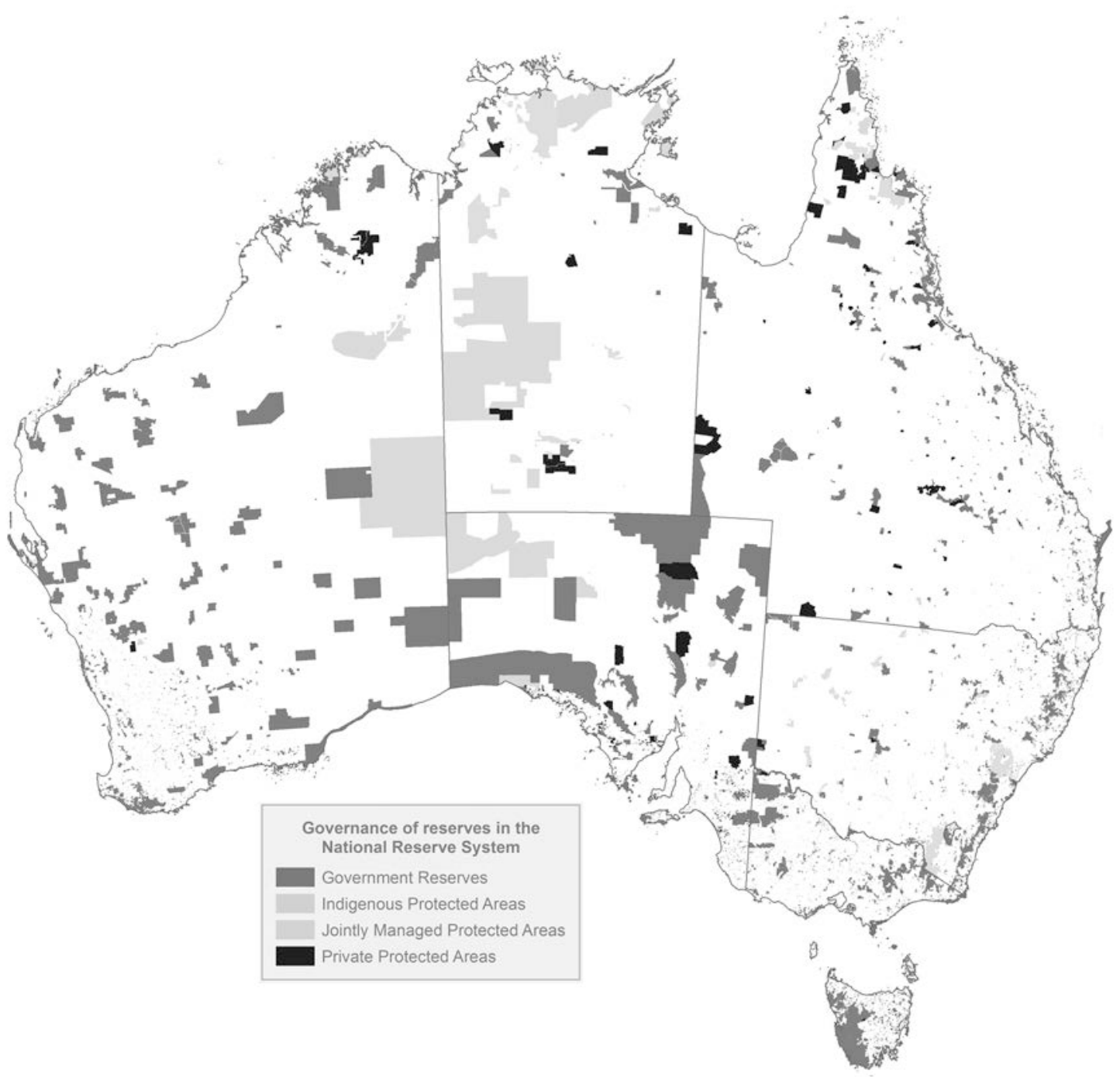

Figure 2: Location and governance of protected areas in Australia’s National Reserve System in 2012. Source: Australian Government (n.d.b). 


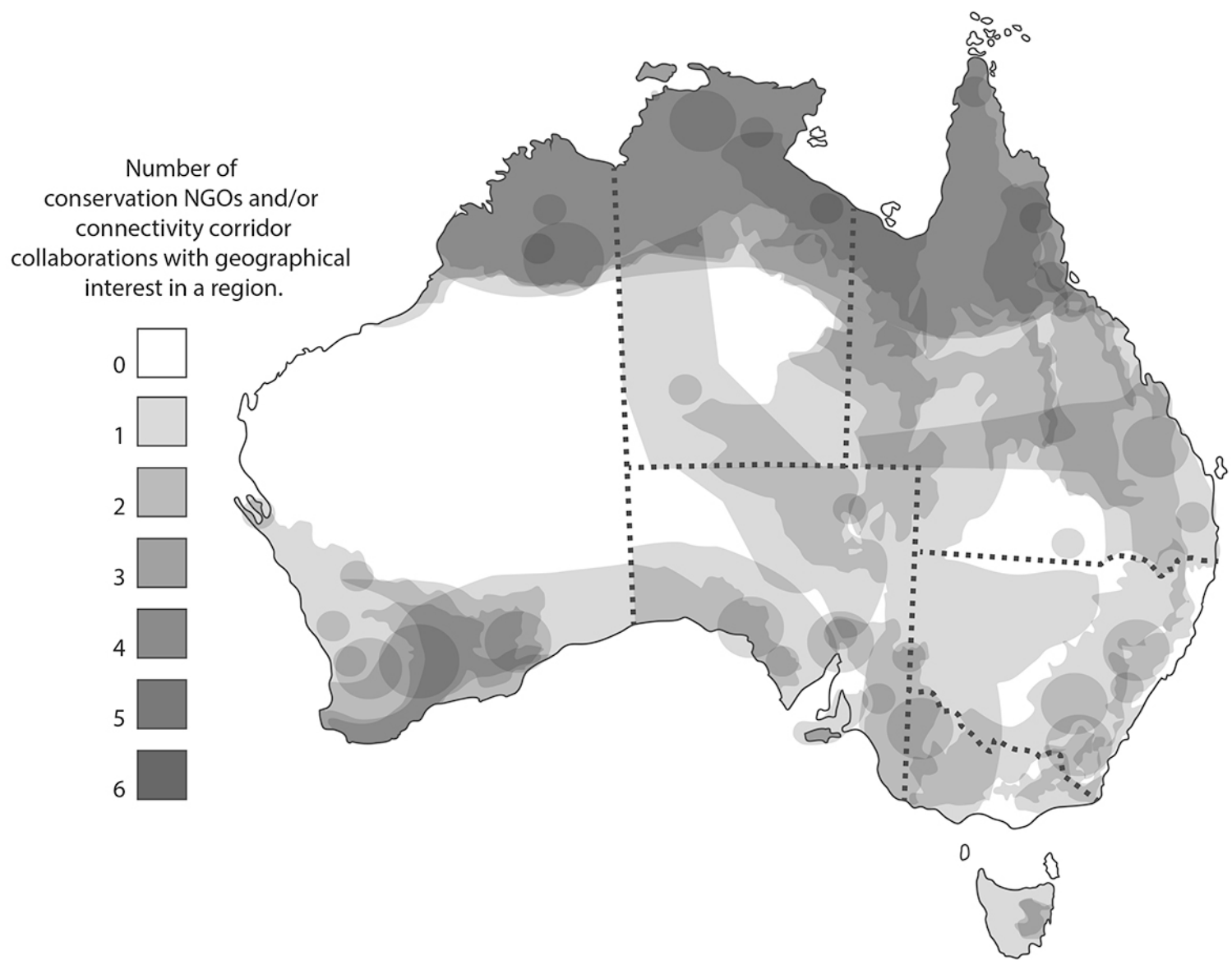

Figure 3: Terrestrial geographical areas of interest, and level of interest, of conservation under the new paradigm in Australia. 
Aboriginal lands

Native Title determinations

Declared Indigenous Protected Areas

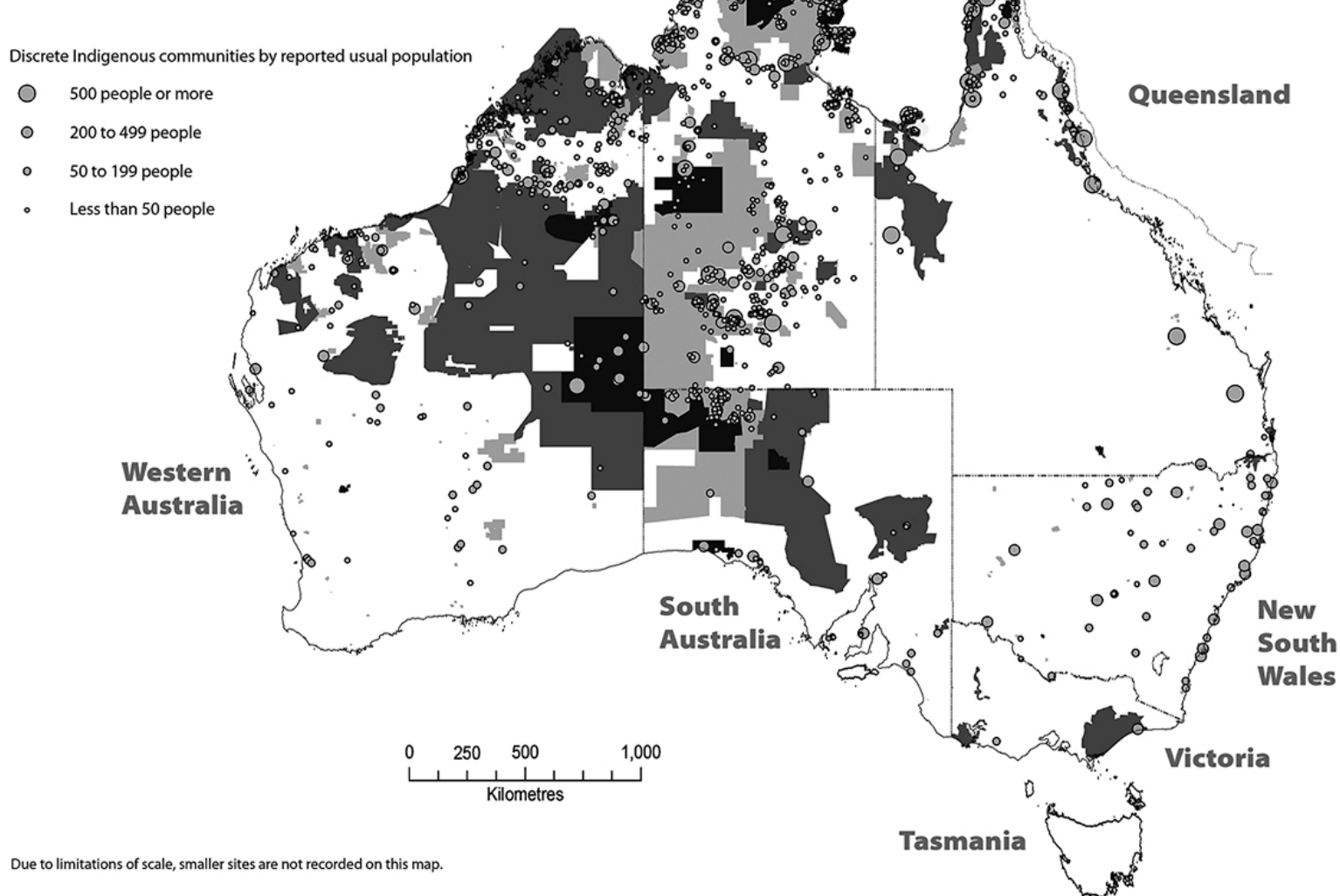

Figure 4: Map of the Indigenous-titled lands in Australia at 2012, also showing discrete Indigenous communities. Source: Altman 2012 @ Federation Press, Sydney. 


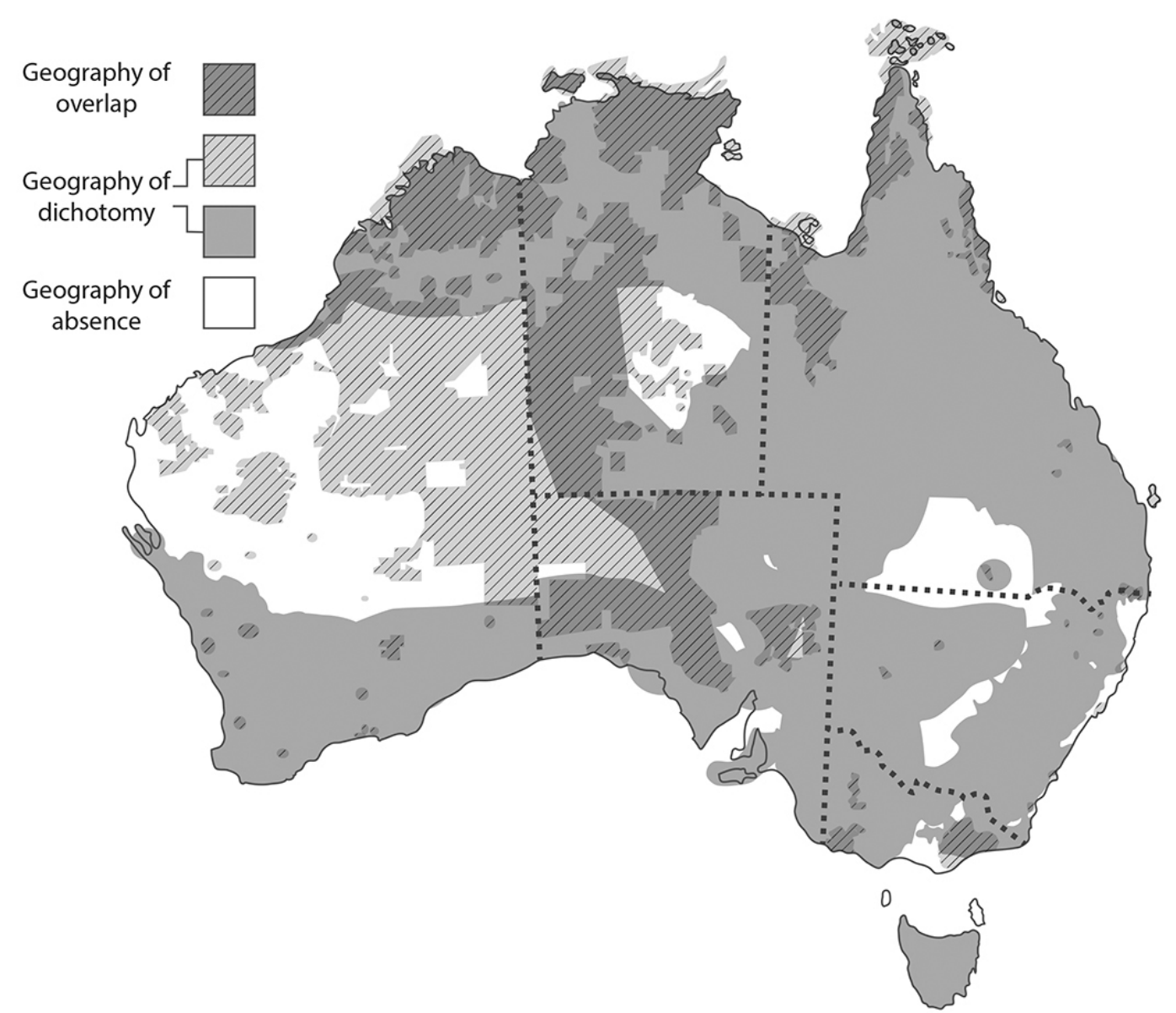

Figure 5: Map showing emerging geographies of conservation and Indigenous land in Australia. (Indigenous lands adapted from Altman (212) @ Federation Press, Sydney). 